\title{
Evaluation of Soybean Meal as a Dietary Protein Source on the Performance of Labeo rohita (Ham.) Spawn Reared under Pond Condition
}

\author{
D. A. Jahan ${ }^{1}$, L. Hussain ${ }^{2}$, M. A. Islam ${ }^{2}$ and A. Naima ${ }^{3}$ \\ ${ }^{1}$ Freshwater Station, Bangladesh Fisheries Research Institute (BFRI), Mymensingh-2201; \\ ${ }^{2}$ Department of Fisheries Biology and Genetics, Bangladesh Agricultural University, Mymensingh- \\ 2202; ${ }^{3}$ Riverine Station, Bangladesh Fisheries Research Institute (BFRI), Chandpur-3602 \\ *Corresponding author and Email: durin_bfri@yahoo.com
}

Received: 06 February 2013

Accepted: 06 December 2013

\begin{abstract}
Growth of Labeo rohita spawn, fed on four formulated (almost iso-nitrogenous and iso-caloric) diets containing fish meal, soybean meal, mustard oil cake and rice bran along with vitamin and mineral premix was studied at the Bangladesh Agricultural University, Mymensingh, during 07 June to 19 July, 2006. Fish meal was replaced by soybean meal at the rates of $0,25,50$ and $75 \%$ in Treatment 1 , 2, 3 and 4, respectively. In a 42-day feeding trial, significantly higher growth rate, feed conversion ratio, protein efficiency ratio and survival rate and slightly higher protein content in carcass were observed in Treatment 2 but the variation was not statistically significant.
\end{abstract}

Keywords: Fish meal, soybean meal, Labeo rohita, rohu, spawn

\section{Introduction}

There is an increasing trend for aquaculture to be dependent on feeds. In 2008, about 31.5 million tones or 46.1 percent of total global aquaculture production were dependent upon the direct use of feed, either as a single ingredient, as farm-made aquafeeds or by the use of industrially manufactured compound aquafeeds (FAO, 2010). Thus, provision of nutritionally balanced diets is the prerequisite for success in any aquaculture practice in Bangladesh along with available quality fish seed. The survival of carps during early stage is usually low, ranging 30$50 \%$ (Keshavappa et al., 1990). Lack of proper care and understanding about the biotic and abiotic factors interacting in the rearing system may results in mass mortality of young fry. A balanced formulated diet may increase the survival rate of fry.
Protein content in the diet has significant effect on growth of carps' fry. Protein requirement for Indian major carps was found to range from 30 to 40\% (Shetty and Nandeesha, 1988). Usually rice bran and mustard oil cake are being used as major supplementary feeds for fish culture in Bangladesh which is reported to be not sufficient to fulfill the requirement of protein. Hossain and Jauncey (2003) and Mohanty et al. (1990) obtained better result with supplementary feed formulated for rearing Indian major carp fry using a number of ingredients of both plant and animal origin. On the other hand, Hecht (2000) opined that expensive feed ingredients have not contributed greatly to aquaculture development. However, most of the feeding trials were conducted under laboratory condition, and only a few field trials have been conducted to evaluate the efficacy of diets on the growth and survival rates of carp species because natural food 
organisms contribute to fish growth in both fed and non-fed ponds (Khan et al., 2012). Jhingran (1991) observed that natural food supplies certain digestive enzymes that improve the utilization of artificial diets. The present study was therefore conducted in the field to evaluate the efficacy of the experimental diets to determine the maximum utilization of soybean meal protein against fish meal protein in rearing of rohu spawn.

\section{Materials and Methods}

\subsection{Location}

The trial was conducted in 12 earthen ponds for a period of 42-days in the Field Laboratory Complex of the Faculty of Fisheries, Bangladesh Agricultural University, Mymensingh during 07 June to 19 July, 2006. The area of each pond was $60 \mathrm{~m}^{2}$ and the average depth of water was maintained at 1.0 to 1.3 meter throughout the experimental period.

\subsection{Treatments and design}

Four treatments, each with three replications were laid out in a Completely Randomized Design. All the diets were formulated carefully to maintain $35 \%$ protein and $13 \%$ lipid level. In the three diets, fish meal protein was replaced by soybean meal protein to the tune of $25 \%$ (Treatment 2), 50\% (Treatment 3) and 75\% (Treatment 4), while Treatment 1 having $100 \%$ fish meal protein was used as control.

\subsection{Feed preparation}

All the dietary ingredients were ground, dried and then mixed well and carefully stored. Diets and dietary ingredients were analyzed for dry matter, moisture, crude protein, crude lipid, ash, gross energy, crude fibre. Nitrogen free extract (NFE) was calculated by subtraction (Table 1). Proportion of feed ingredients and proximate compositions of the formulated diets are presented in Table 2 .

\subsection{Pond preparation and fish stocking}

Ponds were drained out to eradicate predators and weed fishes and then limed at the rate of 250 $\mathrm{kg} \mathrm{ha}^{-1}$. Three days after liming, the ponds were filled up with water to a depth of $1.0 \pm 0.1 \mathrm{~m}$ and fertilized with Urea and Triple super phosphate (TSP) at the rate of $25 \mathrm{~kg} \mathrm{ha}^{-1}$ each and simultaneously, cowdung was applied at the rate of $2500 \mathrm{~kg} \mathrm{ha}^{-1}$ after Kibria et al. (1991). Five days after manuring the ponds were treated with Dipterax at the rate of $5 \mathrm{~kg} \mathrm{ha}^{-1}$ for eradication of aquatic insects and after 24 hours, 4-day old $L$. rohita spawn were stocked in respective ponds at a density of 7,50,000 ha ${ }^{-1}$ according to Hossain and Dewan (1997).

\subsection{Feeding protocol}

From the second day of stocking, spawn were fed twice daily with finely powdered diets containing soybean meal (where applicable), fishmeal, rice bran, mustard oil cake, vitamin and mineral premix according to the design at every morning (8.00-9.00 hr) and afternoon (15:00-16:00 hr). The diets were broadcasted at the rate of 100,50 , $25,15,10$ and 6 per cent of body weight of the stocked spawn in the $1 \mathrm{st}, 2 \mathrm{nd}, 3 \mathrm{rd}, 4 \mathrm{th}, 5 \mathrm{th}$ and 6th week, respectively.

\subsection{Water quality parameters}

Physico-chemical parameters of water like temperature, dissolved oxygen, ammonianitrogen, total alkalinity, secchi depth and $\mathrm{pH}$ were recorded at seven days interval through sampling following a standard method (APHA, 1990) to ensure the water quality within suitable range. Quantitative analysis for phyto and zoo plankton estimation was done according to Bellinger (1992).

\subsection{Growth parameters analyzed}

Specific growth rate (SGR), \% weight gain, food conversion ratio (FCR), protein efficiency ratio (PER) and apparent net protein utilization (ANPU\%) were calculated as follows:

SGR $(\% /$ day $)=[($ Ln. Final body weight - Ln . Initial body weight)/days $\times 100$ ]

Weight gain $(\%)=($ Final body weight - Initial body weight)/Initial body weight $) \times 100$

$\mathrm{FCR}=$ Food fed $(\mathrm{g}$ dry weight $) /$ Live weight gain (g) 
PER $=$ Live weight gain $(\mathrm{g}) /$ Crude protein fed $(\mathrm{g}$ dry weight)

ANPU $(\%)=($ Net increase in carcass protein/Protein consumed) $\times 100$

\subsection{Carcass composition}

At the beginning fifty fishes and at the end twenty fishes were randomly collected from each replication of each treatment and were sacrificed to assess their nutritional value according to AOAC (2003).

\subsection{Statistical analysis}

All the data were subjected to Analysis of Variance (ANOVA) and Duncan's Multiple Range Test was conducted to test significant variations exist among the treatment means.

Table 1. Proximate composition of different ingredients used in the formulated diets ( $\%$ dry matter basis)

\begin{tabular}{lrrrr}
\hline Components & \multicolumn{3}{c}{ Feed Ingredients } \\
\cline { 2 - 4 } & Fish meal & Soybean meal & MOC $^{1}$ & Rice bran \\
\hline Dry matter & $90.96 \pm 0.77$ & $91.81 \pm 0.13$ & $89.57 \pm 0.69$ & $90.17 \pm 0.30$ \\
Crude protein & $58.92 \pm 0.66$ & $43.6 \pm 0.62$ & $28.72 \pm 0.48$ & $11.74 \pm 0.41$ \\
Crude lipid & $15.03 \pm 0.26$ & $14.26 \pm 0.60$ & $11.14 \pm 0.24$ & $10.24 \pm 0.32$ \\
Ash & $22.24 \pm 0.58$ & $5.68 \pm 0.33$ & $10.53 \pm 0.29$ & $10.12 \pm 0.36$ \\
Crude fibre & $1.17 \pm 0.10$ & $5.24 \pm 0.24$ & $13.24 \pm 0.25$ & $13.82 \pm 0.41$ \\
Nitrogen Free Extract & $2.64 \pm 0.19$ & $31.12 \pm 0.20$ & $36.41 \pm 1.24$ & $54.08 \pm 0.25$ \\
\hline
\end{tabular}

${ }^{1}$ Mustard oil cake

Table 2. Proportion of different ingredients and proximate composition of the experimental diets (\% dry weight)

\begin{tabular}{lrrrr}
\hline Ingredients & \multicolumn{4}{c}{ Diets } \\
& $\mathrm{T}-1$ & $\mathrm{~T}-2$ & $\mathrm{~T}-3$ & $\mathrm{~T}-4$ \\
\hline Fish meal & 49.00 & 36.75 & 24.50 & 12.25 \\
Soybean meal & 00.00 & 16.78 & 33.57 & 50.33 \\
Mustard oil cake & 4.50 & 6.50 & 9.50 & 13.50 \\
Rice bran & 43.50 & 36.97 & 29.43 & 20.92 \\
Vitamin and mineral premix & 3.00 & 3.00 & 3.00 & 3.00 \\
\hline Proximate composition & & & & \\
\hline Crude protein & $35.12 \pm 0.25$ & $35.22 \pm 0.22$ & $35.09 \pm 0.16$ & $35.38 \pm 0.24$ \\
Crude lipid & $12.69 \pm 0.37$ & $12.56 \pm 0.34$ & $12.72 \pm 0.29$ & $12.78 \pm 0.31$ \\
Ash & $15.78 \pm 0.42$ & $13.68 \pm 0.26$ & $11.41 \pm 0.28$ & $09.22 \pm 0.26$ \\
Crude fibre & $7.25 \pm 0.17$ & $7.29 \pm 0.28$ & $7.37 \pm 0.29$ & $7.45 \pm 0.27$ \\
Nitrogen free extract & $29.16 \pm 1.19$ & $31.25 \pm 1.09$ & $33.41 \pm 1.01$ & $35.17 \pm 1.08$ \\
Gross energy (kJ/g) & $17.93 \pm 0.16$ & $18.26 \pm 0.04$ & $18.66 \pm 0.05$ & $19.06 \pm 0.04$ \\
PE ratio & $19.59 \pm 0.35$ & $19.29 \pm 0.17$ & $18.80 \pm 0.15$ & $18.57 \pm 0.17$
\end{tabular}

${ }^{\mathrm{a}}$ Protein to energy ratio in $\mathrm{mg}$ protein/KJ of gross energy 


\section{Results and Discussion}

The water quality parameters as recorded from the experimental ponds during the study period are presented in Table 3. Growth performance, protein utilization, feed efficiency and feed consumption of fishes are normally governed by some environmental factors. Quddus and Banerjee (1989-1991) mentioned that physicochemical parameters are the important limiting factors of a water body, which directly or indirectly influence the primary and secondary productivity of the water body. Water temperature during the study period was found to vary from 28.1 to $30.8{ }^{\circ} \mathrm{C}$ which is considered to be favorable for fish growth. Goolish and Adelman (1984) obtained the maximum growth rate at $30{ }^{\circ} \mathrm{C}$ in case of juvenile common carp. Average dissolved oxygen, secchi depth, total alkalinity, ammonia and $\mathrm{pH}$ value of the experimental ponds were found to range from 5.53 to $5.60 \mathrm{mgL}^{-1}, 26.45$ to $29.42 \mathrm{~cm}, 85.25$ to $98.72 \mathrm{mgL}^{-1}, 0.11-0.12 \mathrm{mgL}^{-1}$ and 7.17 to 7.36 $\mathrm{mgL}^{-1}$, respectively which were suitable for optimum growth of fish. Treatment variation in respect of water quality parameters was not statistically significant $(\mathrm{P}>0.05)$ and was found to be always within the suitable range for aquaculture.

The abundance of planktonic population in water of the experimental ponds was found to range from $23.92 \pm 3.31$ to $39.82 \pm 3.76 \times 10^{3} \mathrm{~L}^{-1}$ during the study period and no significant differences was found in planktonic population among the treatments. So, it might be presumed that the impacts of environmental factor on survival, growth performance and carcass composition of the fishes belonging to different treatments were the same. Sohail (2010) observed that abundance of natural food organisms exerts impact on increasing fish growth.

The average survival rate was obtained to be 64.67, 71, 67 and 58.33\% in Treatment 1, 2, 3 and 4, respectively. Hossain and Dewan (1997) obtained $38.4 \%$ survival rate in $L$. rohita spawn using mustard oil cake and rice bran (1:1) as supplementary feed. Banergee et al. (1979) reported that growth and survival of spawn depends on stocking density, available food, type and availability of fertilizer and duration of the study period.

Protein rich diet plays an important role at different stage of life for optimizing carp growth. Mohanty et al. (1990) reported that a dietary protein level over $45 \%$ inhibited the growth of $L$. rohita fry. In the present study 35\% protein level was maintained for all the Treatments and the protein level did not appear to inhibit the growth rather enhanced it. The growth of fishes fed on experimental diets showed significant difference $(P>0.05)$ in length and weight compared to the control diet (Table 4).

Khan et al. (2012) obtained satisfactory result using $35 \%$ protein in terms of weight gain. Length and weight of rohu fry were found to be $61.50 \pm 2.34 \mathrm{~mm}$ and $1878.33 \pm 26.03 \mathrm{mg}$ in Treatment 2 as against $55.42 \pm 0.87 \mathrm{~mm}$ and $1516.67 \pm 23.46 \mathrm{mg}, 58.56 \pm 0.67 \mathrm{~mm}$ and $1719.33 \pm 26.03 \mathrm{mg}, 50.73 \pm 1.04 \mathrm{~mm}$ and $1393.33 \pm 27.27 \mathrm{mg}$ in Treatments 1,3 and 4 , respectively (Table 4). The differences were probably due to proper ratio of the feed ingredients. Hossain and Dewan (1997) obtained the highest growth in L. rohita using inorganic fertilizer and supplementary feed consisting of mustard oil cake and rice bran (1:1). SGR value indicates the nutritional value of a diet and also defines the relationship between growth and feeding rate. In treatment 2 , good profile of the diet gave better growth performance, lower FCR, PER and higher SGR value.

In all the treatments, carcass composition (crude protein, crude lipid and ash) was found to increase from the initial level and fishes belonging to treatment 2 showed higher protein level than those of the other treatments (Table 5) which also indicates the efficacy of the diets. Non significant differences among the treatments in respect of protein and lipid content in our experiment agree with the findings of 
Pongmaneerat and Watanabe (1993) who reported that carp body protein was not markedly influenced by soybean meal. Through incorporation of plant protein by replacing fish meal, El Saidy and Gober (2003) did not find any significant effect on the whole body composition of Oreochromis niloticus. Jena et al. (1996) also obtained similar results while working with
Indian major carp spawn under field condition. It may be mentioned that rearing of $L$. rohita spawn under field condition, plankton and other aquatic sources may meet the amino acid deficiency of soybean meal. In this study, it was observed that a combination of plant and animal protein was more acceptable to $L$. rohita larvae than only fish meal protein.

Table 3. The water quality parameters (average \pm SD) as recoded from the experimental ponds belonging to different Treatments

\begin{tabular}{lrrrrr}
\hline Parameters & \multicolumn{4}{c}{ Diets } & \multirow{2}{*}{ F-value } \\
\cline { 2 - 5 } & \multicolumn{1}{c}{$\mathrm{T}-1$} & \multicolumn{1}{c}{$\mathrm{T}-2$} & \multicolumn{1}{c}{$\mathrm{T}-3$} & \multicolumn{1}{c}{$\mathrm{T}-4$} & \\
\hline Water temperature $\left({ }^{\circ} \mathrm{C}\right)$ & $29.59 \pm 0.09$ & $29.75 \pm 0.09$ & $29.66 \pm 0.12$ & $29.69 \pm 0.03$ & $1.78^{\mathrm{NS}}$ \\
Dissolved oxygen $\left(\mathrm{mgL}^{-1}\right)$ & $5.58 \pm 0.07$ & $5.48 \pm 0.05$ & $5.53 \pm 0.03$ & $5.60 \pm 0.04$ & $3.793^{\mathrm{NS}}$ \\
Ammonia $\left(\mathrm{mgL}^{-1}\right)$ & $0.11 \pm 0.01$ & $0.12 \pm 0.01$ & $0.12 \pm 0.01$ & $0.11 \pm 0.01$ & $1.833^{\mathrm{NS}}$ \\
Secchi depth $(\mathrm{cm})$ & $27.87 \pm 0.47$ & $29.42 \pm 1.63$ & $28.70 \pm 1.31$ & $26.45 \pm 0.85$ & $3.666^{\mathrm{NS}}$ \\
Total alkalinity $\left(\mathrm{mgL}^{-1}\right)$ & $88.73 \pm 6.04$ & $98.72 \pm 5.82$ & $92.73 \pm 5.37$ & $85.25 \pm 5.59$ & $3.077^{\mathrm{NS}}$ \\
pH & $7.21 \pm 0.27$ & $7.36 \pm 0.06$ & $7.26 \pm 0.21$ & $7.17 \pm 0.35$ & $0.347^{\mathrm{NS}}$ \\
\hline
\end{tabular}

NS=Non significant

Table 4. Performance of L. rohita spawns as obtained from different Treatments

\begin{tabular}{lrrrrr}
\hline \multirow{2}{*}{ Components } & \multicolumn{4}{c}{ Diets } & \multirow{2}{*}{ F-value } \\
\cline { 2 - 5 } & \multicolumn{1}{c}{$\mathrm{T}-1$} & \multicolumn{1}{c}{$\mathrm{T}-2$} & \multicolumn{1}{c}{$\mathrm{T}-3$} & \multicolumn{1}{c}{$\mathrm{T}-4$} & \\
\hline Initial length $(\mathrm{mm})$ & $6.13 \pm 0.40$ & $6.08 \pm 0.20$ & $6.04 \pm 0.16$ & $6.03 \pm 0.10$ & $0.361^{\mathrm{NS}}$ \\
Final length $(\mathrm{mm})$ & $55.42^{\mathrm{c}} \pm 0.87$ & $61.50^{\mathrm{a}} \pm 2.34$ & $58.06^{\mathrm{b}} \pm 0.67$ & $50.73^{\mathrm{d}} \pm 1.04$ & $31.91^{* *}$ \\
Initial weight $(\mathrm{mg})$ & $1.67 \pm 0.01$ & $1.67 \pm 0.01$ & $1.67 \pm 0.01$ & $1.67 \pm 0.01$ & - \\
Final weight $(\mathrm{mg})$ & $1516.67^{\mathrm{c}} \pm 23.46$ & $1878.33^{\mathrm{a}} \pm 26.03$ & $1719.33^{\mathrm{b}} \pm 26.03$ & $1393.33^{\mathrm{d}} \pm 27.79$ & $32.62^{* *}$ \\
SGR (\%/day) & $16.22^{\mathrm{c}} \pm 0.14$ & $16.73^{\mathrm{a}} \pm 0.13$ & $16.51^{\mathrm{b}} \pm 0.07$ & $16.02^{\mathrm{d}} \pm 0.05$ & $134.08^{* *}$ \\
FCR & $1.28^{\mathrm{ab}} \pm 0.16$ & $1.21^{\mathrm{c}} \pm 0.09$ & $1.24^{\mathrm{bc} \pm 0.15}$ & $1.32^{\mathrm{a}} \pm 0.13$ & $8.00^{* *}$ \\
PER & $2.27^{\mathrm{ab}} \pm 0.08$ & $2.37^{\mathrm{a}} \pm 0.14$ & $2.32^{\mathrm{a}} \pm 0.19$ & $2.17^{\mathrm{b}} \pm 0.14$ & $5.281^{*}$ \\
Survival rate $(\%)$ & $64.67^{\mathrm{b}} \pm 2.52$ & $73.33^{\mathrm{a}} \pm 3.06$ & $65.00^{\mathrm{b}} \pm 1.00$ & $58.33^{\mathrm{c}} \pm 1.53$ & $23.906^{* *}$ \\
\hline
\end{tabular}

$*$ and $* *$ significant at $5 \%$ and $1 \%$, respectively, NS=Non significant

Table 5. Carcass composition of L. rohita spawn and fry belonging to different treatments (\% fresh weight)

\begin{tabular}{|c|c|c|c|c|c|c|c|}
\hline \multirow[t]{2}{*}{ Component } & \multirow[t]{2}{*}{ Initial } & \multicolumn{4}{|c|}{ Diets } & \multirow[t]{2}{*}{ F-value } & \multirow[t]{2}{*}{$\pm \mathrm{SE}$} \\
\hline & & $\mathrm{T}-1$ & $\mathrm{~T}-2$ & $\mathrm{~T}-3$ & $\mathrm{~T}-4$ & & \\
\hline Moisture & $90.61 \pm 0.60$ & $85.56 \pm 0.88$ & $85.11 \pm 1.02$ & $84.95 \pm 0.97$ & $85.32 \pm 0.95$ & $0.23^{\mathrm{NS}}$ & 0.25 \\
\hline Crude protein & $7.67 \pm 0.31$ & $10.89 \pm 0.39$ & $11.39 \pm 0.54$ & $11.24 \pm 0.66$ & $10.80 \pm 0.53$ & $0.81^{\mathrm{NS}}$ & 0.15 \\
\hline Crude lipid & $1.44 \pm 0.13$ & $2.35 \pm 0.34$ & $2.26 \pm 0.32$ & $2.31 \pm 0.19$ & $2.44 \pm 0.28$ & $0.21^{\mathrm{NS}}$ & 0.07 \\
\hline Ash & - & $0.99 \pm 0.13$ & $0.94 \pm 0.09$ & $0.93 \pm 0.09$ & $0.95 \pm 0.08$ & $0.21^{\mathrm{NS}}$ & 0.02 \\
\hline
\end{tabular}

NS $=$ Non significant 


\section{Conclusions}

From the study, it may be concluded that fish meal may safely be replaced by soybean meal in rearing of rohu spawn up to $25 \%$ levels in the field condition where exogenous foods i.e. plankton and other aquatic organisms are available.

\section{References}

AOAC (Association of Official Analytical Chemists). 2003. Official Methods of Analysis, $17^{\text {th }}$ edn., Washington, D.C., USA.

APHA. 1990. Standard Methods for the Examination of Water and Waste Water. American Public Health Association, New York, 1193 p.

Banergee, P. K., Ray, P., Singait, G. S. and Dutta, B. R. 1979. Poultry droppings : its manurial potentiality in aquaculture. Journal of Inland Fisheries Society of India, 2(1): 94-108.

Bellinger, E. G. 1992. A key to common algae: Freshwater estuarine and some coastal species. The Institute of Water and Environmental Management, London, UK, 138 pp.

El Saidy, D. M. S. D. and Gaber, M. M. A. 2003. Replacement of fishmeal with a mixture of different plant protein sources in juvenile Nile tilapia, Oreochromis niloticus (L.) diets. Aquatic Research, 34: 1119-1127.

FAO. 2010. Fishstat Plus: universal software for fishery statistical time series. Aquaculture production: quantities 1950-2008; Aquaculture production: values 19842008; Capture production: 1950-2008; Commodities production and trade: 19502008; Total production: 1970-2008, Vers. 2.30. FAO Fisheries Department, Fishery Information, Data and Statistics Unit. (available

at: www.fao.org/fi/statist/FISOFT/FISHPLU S.asp).

Goolish, E.M. and Adelman, I.R. 1984. Effects of ration size and temperature on the growth of juvenile common carp (Cirrhinus carpio L.). Aquaculture, 36 : 27-35.

Hetch, T. 2000. Consideration of African Aquaculture. Journal of World Aquaculture, 31: 12-19.

Hossain, M. A. and Jauncey, K. 2003. Studies on the protein, energy and amino acid digestibility of fish meal, mustard oilcake, linseed and sesame meal for common carp (Cyprinus carpio L.). Available online. http://dx.doi.org/10.1016/00448486(89)90060-4.

Hossain, M. S. and Dewan, S. 1997. A study on the growth and survival of the spawns of different carps in nursery ponds. Bangladesh Journal of Fisheries, 20(1-2): 111-115.

Jena, J. K., Mukhopadhyay, P. K., Sarkar, S., Aravindakshan, P. K. and Muduli, H. K. 1996. Evaluation of a formulated diet for nursery rearing of Indian major carp under field condition. Journal of Aquaculture in the Tropics, 11: 299-305.

Jhingran, V. G. 1991. Inland Fisheries of India and Adjacent Countries. Vol. I. Oxford and IBH Publishing Co. Pvt. Ltd. Calcutta. $541 \mathrm{p}$.

Keshavappa, G. Y., Dovaraj, K. V., Basavaraju, Y. and Seenappa, D. 1990. Survival and growth of common carp spawn fed on soybean flour. Journal of Aquaculture in the Tropics, 5:131-134.

Khan, N., Ashraf, M., Qureshi, N. A., Sarker, P. K., Vandenberg, G. W. and Rasool, F. 2012. Effect of similar feeding regime on growth and body composition of Indian major carps (Catla catla, Cirrhinus mrigala and Labeo rohita) under mono and polyculture. African Journal of Biotechnology, 11(44):10280-10290.

Kibria, M. G., Barua, G. and Hossain, M. A 1991. Effects of cowdung on the phytoplankton production of the nursery pond. Bangladesh Journal of Fisheries, 4 (1-2): 47-52.

Mohanty, S. N., Swami, D. N. and Tripathi, S. D. 1990. Protein utilization in Indian major 
carp fry Catla catla (Ham.), Labeo rohita (Ham.), and Cirrhinus mrigala (Ham.) fed four protein diets. Journal of Aquaculture in the Tropics, 5: 173-179.

Pongmaneerat, J. and Watanabe, T. 1993. Nutritional evaluation of soybean meal for rainbow trout and carp. Nippon Suisan Gakkaishi, 59(1): 157-163.

Quddus, M. M. A. and Banerjee, A. K. 19891991. Diurnal variations in the physicochemical parameters of a nursery ponds. Bangladesh Journal of Aquaculture, 11-13 (1-2): 47-51.
Shetty, H. P. C. and Nandeesha, M. C. 1988. An overview of carp nutrition research in India. In: Fin fish nutrition research in Asia, Proceedings of the Second Asian Fish Nutrition Network Meeting [De Silva S.S. (ed.)]. Heenemann Asia, Singapore. 96-116.

Sohail, M. 2010. Variation of the primary and secondary productivity in mono and polyculture system of fish pond. M. Phil. Thesis, Department of Fisheries and Aquaculture, Uni. Vet. Ani. Sci., Lahore. $72-73 \mathrm{pp}$. 